\title{
Effect of Predator Exclusion on Cassava Infested with Tetranychid Mites (Acari: Tetranychidae)
}

\author{
A. R. BRAUN, A. C. BELLOTTI, J. M. GUERRERO, \\ AND L. T. WILSON ${ }^{1}$ \\ Cassava Program, Centro Internacional de Agricultura Tropical, \\ Cali, Colombia
}

\begin{abstract}
Environ. Entomol. 18(4): 711-714 (1989)
ABSTRACT Chemical exclusion of predators with permethrin was used to test the effectiveness of the phytoseiid predator Amblyseius limonicus Garman and McGregor and a complex of minor predators in the biological control of tetranychid (Mononychellus spp., Tetranychus spp., and Oligonychus peruvianus McGregor) pests of cassava, Manihot esculenta Crantz. Mononychellus spp. and Tetrunychus spp. populations were significantly higher and predator populations significantly lower in permethrin-treated plots than in control plots. Numbers of O.peruviunus were not affected by permethrin. Yield of fresh commercial roots and of dry matter was significantly higher in plots with predators than in plots where permethrin was applied every $\mathbf{2}$ wk for predator exclusion. Yields of neither fresh nor dry matter in control plots were significantly different from yields in plots that had been protected with acaricide, suggesting that predation kept spider mite populations below economically damaging levels.
\end{abstract}

KEY WORDS Arachnida, cassava, permethrin, predator exclusion

Cassava, Manihot esculenta Crantz, is the most important starchy root crop in the tropics. Although considered to be relatively pest tolerant, recent research has shown that pests that are present throughout the growing cycle (e.g., spider mites) can depress cassava yield (Cock 1985).

The tetranychid, Mononychellus tanajoa (Bondar), was accidentally introduced to Africa from tropical America and has spread to 21 of the $\mathbf{3 4}$ African cassava-growing countries (IITA 1985).The absence of natural enemies is thought to be a major factor limiting the control of M. tanajoa in Africa. The objective of our study was to determine the effect of natural enemies in control Monony. chellus spp. and a related complex of tetranychids in their area of origin.

One method of evaluating natural enemies is through the use of selective pesticides. Braun et al. (1987a) showed that permethrin could be used to eliminate Amblyseius limonicus Garman and McGregor, the most common phytoseiid predator in cassava in tropical America (Bellotti et al. 1987). The minor predators Oligota minuta Cameron (Coleoptera: Staphylinidae), Stethorus spp. (Coleoptera: Coccinellidae), and spiders also are susceptible to permethrin (Braun et al. 1987b). Nonlethal side effects of permethrin in the cassavatetranychid mite ecosystem such as phytostimulation and enhancement of phytophagous mite fe-

Any opinions, findings, conclusions, or recommendations expressed in this publication are those of the authors and do not necessarily reflect the views of the National Science Foundation.

I Department of Entomology, University of California, Davis, Calif. 95616 cundity were found to be of negligible importance (Braun et al. 1987b).

An advantage of selective pesticides over other techniques of predator exclusion, such as caging, is that they can be applied in large-scale field studies, permitting the use of yield as a criterion for evaluating predator efficacy. Although yield data are generally reported in studies of biological control with microbial agents, yield differences found in experiments with natural enemies of insects and mites are rarely published.

\section{Materials and Methods}

A predator-exclusion experiment was designed to measure the effect of mite predators on cassava mite abundance and on commercial fresh-root and dry-matter yield. Four cassava clones-MCol 22, CG5-79, 'Montero,'and 'Venezolana'-were planted at a density of 10,000 plants/ha in October 1984 on a farm in the arid northern coastal region of Colombia. The design was a split plot with four blocks, with clone as the main factor and pesticide treatment as the subplot factor. Each subplot contained 48 plants. The between-plot distance was 1 $m$. The pesticide treatments were permethrin application every 2 wk (6 g [AI]/100 liters Ambush 50 ; BASF, Federal Republic of Germany) for elimination of predators; acaricide treatment every 2 wk (Tedion V-18; 2,000g [AI]/ 100 liters tetradifon; N. V. Phillips Duphar, Amsterdam); and an unsprayed control with natural populations of predators and phytophagous mites. A gasoline-powered 
Table 1. Overall univariate analyses from repeated-measures ANOVA for effect of clone and pesticide treatment on tetranyehid mites and $A$. limonicus in cassava

\begin{tabular}{|c|c|c|c|c|c|c|c|c|c|}
\hline \multirow{3}{*}{ Factor } & \multirow{3}{*}{$\mathrm{df}$} & \multicolumn{8}{|c|}{ Specie9 } \\
\hline & & \multicolumn{2}{|c|}{ M. progresivus } & \multicolumn{2}{|c|}{ T. urticae } & \multicolumn{2}{|c|}{ O.peruvianus } & \multicolumn{2}{|c|}{ A. limonicus } \\
\hline & & MS & $F$ & MS & $F$ & MS & $F$ & MS & $F$ \\
\hline \multicolumn{10}{|l|}{ Whole units } \\
\hline Block & 3 & 0.01 & 0.8 & 0.01 & 0.2 & 0.09 & 0.6 & 0.83 & 0.6 \\
\hline $\begin{array}{l}\text { Pesticide } \\
\text { Error }\end{array}$ & 312 & $\begin{array}{l}0.42 \\
0.02\end{array}$ & $23.1^{* * *}$ & $\begin{array}{l}5.36 \\
0.08\end{array}$ & $64.9^{* * *}$ & $\begin{array}{l}5.92 \\
0.16\end{array}$ & $38.0^{* * *}$ & $\begin{array}{r}45.57 \\
1.35\end{array}$ & $33.7^{* * *}$ \\
\hline \multicolumn{10}{|l|}{ Subunits } \\
\hline Clone & 3 & 0.46 & $28.2^{* * *}$ & 0.63 & $28.8^{* * *}$ & 0.01 & 0.3 & 12.77 & $45.9^{* * *}$ \\
\hline $\mathrm{C} \times \mathrm{P}$ & 6 & 0.11 & $7.0^{* * *}$ & 0.13 & $6.0^{* *}$ & 0.04 & 2.0 & 5.03 & $18.1^{* * *}$ \\
\hline Error & 9 & 0.02 & & 0.02 & & 0.02 & & 0.28 & \\
\hline
\end{tabular}

$a^{* *}$, significant $(\boldsymbol{P} \leq \mathbf{0 . 0 5}) ; * * *$ significant $(P \leq 0.01)$; MS, mean square.

backpack sprayer (16 liter) was used to apply pesticides as described in Braun et al. (1987a). Pesticide treatments were initiated 1,480 degree-days (DD) (16 wk) after planting. Degree-days were calculated as described by Gilbert et al. (1976), using the estimate of Keating et al. (1979) of the thermal threshold of cassava $\left(13^{\circ} \mathrm{C}\right)$.

Because $M$. progresivus and $M$. caribbeanae McGregor are difficult to distinguish in the field, they were recorded as a single category. Likewise, Tetranychus urticae Koch, T. cinnabarinus (Boisduval), and Oligonychus gossypii Zacher also were recorded as a single category (referred to as $\mathrm{Te}$ tranychus spp.). Oligonychus peruvianus McGregor was recorded as a separate category. Densities of other cassava pests were extremely low and were not recorded. Phytophagous mites were evaluated by visually inspecting 40 leaves from the 15 th node chosen at random in each subplot and recording the presence or absence of motile stages as described in Braun et al. (1987a). The youngest fully expanded leaf in the plant terminal is node 1 for the purposes of this study. The data for each subplot were expressed as the proportion of leaves infested, transformed (arcsine square root), and analyzed by repeated-measures analysis of variance (ANOVA) (SAS Institute 1985). Because the results were the same for the transformed and the original data, only the latter are presented. The predator A. limonicus was evaluated directly in the field by counting all stages except eggs on 20 leaves per subplot. Leaves inspected for A. limonicus also were randomly selected from the 15 th node; however, A. limonicus and the phytophagous mites were sampled independently.

Sampling was begun at 1,340 DD (15 wk) after planting. Phytophagous mites and A. limonicus numbers were estimated every 2 wk on seven sampling dates. The first date preceded the first pesticide treatment by $1 \mathrm{wk}$. Commercial fresh-root yield in kilograms per hectare was estimated by weighing all the commercial roots from 16 central plants in each subplot 7 mo after planting. Drymatter yield was calculated by the method of Toro $\&$ Cañas (1982). The yield data were analyzed by analysis of variance.

\section{Results and Discussion}

The effect of date was significant for all species $(\mathrm{P} \leq 0.05 ; \mathrm{df}=6$; M. progresivus: Wilk's lambda $=0.227 ; \mathrm{F}=10.8 ; T$. urticae: Wilk's lambda $=$ $0.010, \mathrm{~F}=326.7 ;$ O.peruvianus: Wilk's lambda $=$ $0.003, \boldsymbol{F}=446.5$; A. limonicus: Wilk's lambda $=$ $0.124, \mathrm{~F}=22.4)$. The effect of pesticide treatment was significant $(\mathrm{P} \leq 0.05)$ for all species for all dates after spraying started. The effect of clone was significant $(\mathrm{P} \leq 0.05)$ on all dates for $M$. progresivus and $\boldsymbol{O}$.peruvianus, on all but the final date for T.urticae, and on all but the last two dates for A. limonicus. The multiple comparisons presented below are based on the overall univariate analyses from repeated-measures ANOVA (Table 1).

Clone. There were no significant differences in populations of O.peruvianus on different clones; however, CG5-79 had a significantly higher proportion of leaves infested with Mononychellus spp. $(\mathrm{P} \leq 0.05)$, the lowest mean number of A. limonicus per leaf, and the lowest fresh- and dry-matter yields (Table 2). 'Venezolana,'a local clone rated as resistant by farmers, was the highest yielder ( $P$ 0.05), had the lowest populations of Mononychellus spp. and Tetranychus spp., and had significantly higher populations of A. limonicus than any other clone except $\mathrm{MCol} 22$ ( $\begin{aligned} & \boldsymbol{P} \\ & \mathbf{0}\end{aligned} \mathbf{0 . 0 5}$; Table 2). MCol 22 is susceptible to Mononychellus spp. and Tetranychus spp.; however, its fresh yield was not significantly different from that of 'Venezolana' despite supporting the greatest proportion of leaves infested with Tetranychus spp. This good yield performance in a susceptible clone may have been because of the relative abundance of A. Zimonicus.

Although A. limonicus prefers Mononychellus spp. as prey (Bellottiet al. 1987), it was least abundant on CG5-79, which had the greatest proportion of leaves infested with Mononychellus spp. Because phytoseiids consume partially digested plant sap that they extract from the guts of their phytophagous prey (Chant 1985), the low abundance of A. limonicus on CG5-79 may reflect the presence of some unfavorable host plant factor.

Predator Exclusion. Fresh- and dry-matter yields were 33 and $26 \%$ lower, respectively, in the pred- 
Table 2. Effect of clone on cassava dry-matter and fresh yield and on populations of tetranychid mites and the predator $A$, limonicus.

\begin{tabular}{|c|c|c|c|c|c|c|}
\hline \multirow[b]{2}{*}{ Clone } & \multicolumn{2}{|c|}{ Yield“" } & \multicolumn{4}{|c|}{ Proportion of infested leaves } \\
\hline & Dry & Fresh & $\begin{array}{l}\text { Mononychellus } \\
\text { spp. }\end{array}$ & $\begin{array}{l}\text { Tetranychw } \\
\text { spp }\end{array}$ & $\begin{array}{l}\text { Oligonychus } \\
\text { spp. }\end{array}$ & $\begin{array}{l}\text { A. limonicus } \\
\text { mean no./leaf }\end{array}$ \\
\hline 'Venezolana' & $5,53 B A$ & $15,365 \mathrm{~A}$ & $0.03 B$ & $0.24 B$ & $0.48 \mathrm{~A}$ & $0.86 \mathrm{~A}$ \\
\hline MCol 22 & $3,409 B$ & $10,391 \mathrm{AB}$ & 0.048 & $0.41 \mathrm{~A}$ & $0.49 A$ & $0.93 \mathrm{~A}$ \\
\hline 'Montero' & $3,551 \mathrm{~B}$ & $10,156 \mathrm{AB}$ & $0.06 \mathrm{~B}$ & $0.37 \mathrm{~A}$ & $0.49 A$ & $0.25 \mathrm{~B}$ \\
\hline CG5-79 & $2,889 \mathrm{~B}$ & $9,375 \mathrm{~B}$ & $0.19 \mathrm{~A}$ & $0.25 \mathrm{~B}$ & $0.48 \mathrm{~A}$ & $0.20 \mathrm{~B}$ \\
\hline
\end{tabular}

Means and proportions followed by the same letter are not significantly different ( $P \leq 0.05$; Scheffe's test [Steel \& Torrie 19801).

$a$ Yields expressed as $\mathrm{kg} / \mathrm{ha}$.

ator-exclusion treatment than in the unsprayed treatment where predators were present $(P \leq 0.05)$ (Table 3). The unsprayed plots had significantly higher numbers of A. limonicus $(P \leq 0.05)$ and significantly lower proportions of leaves infested with Mononychellus spp. and Tetranychus spp. (Table 3). O.peruwianus was not affected by the predator-exclusion treatment (Table 2); however, no difference was expected because this mite lives under dense webbing and apparently is difficult for predators to capture. Fresh- and dry-matter yields in acaricide-treated plots were not significantly different from those in unsprayed plots (Table 3), suggesting that predators were successful in keeping mite densities below economically damaging levels. Monon ychellus spp. and Tetranychus spp. infested 49 and $43 \%$ fewer leaves, respectively, in the unsprayed plots compared with the exclusion plots (Table 3); however, this result may have been influenced by a repellent effect of permethrin on these mites. Permethrin stimulates $T$. urticae dispersal away from treated areas (Iftner \& Hall 1983), so some migration from treated to unsprayed plots may have occurred. A possible repellency effect of permethrin on $M$. progresivus also has been suggested (Braun et al. 1987b).

A. limonicus strongly prefers $M$. progresivus to $\boldsymbol{T}$. urticae as prey (Bellotti et al. 1987), therefore, the role of A. limonicus in regulation of $\boldsymbol{T}$. urticae in the unsprayed plots possibly was small. Minor predators such as O. minuta, Stethorus spp., and spiders, which also were eliminated by permethrin in the predator exclusion plots, may have contributed to T. urticae control (Braun et al. 1987b). At peak densities, Mononychellus spp. infested 25\% of leaves at node 15 compared with peaks of 75 and 100\%for Tetranychus spp. and O.peruvianus, respectively. A. limonicus and generalist predators may have been responsible for confining Mononychellus spp. to a smaller proportion of infested leaves. In contrast, Tetranychus spp. (which suffered predation only by generalists) and O. peruvianus (which was protected from predation by webbing) had intermediate and high proportions of infested leaves, respectively, in the unsprayed plots.

\section{Acknowledgment}

We thank Argemiro Caicedo and Jose Antonio Puente for technical assistance and Juan Miguel Vengoechea for the use of land on his farm. This material is based upon work supported under a National Science Foundation predoctoral fellowship, a Fulbright-Hays fellowship, and the Cassava Program at Centro Internacional de Agricultura Tropical.

\section{References Cited}

Bellotti, A. C., N. Mesa, M. Serrano, J. M. Guerrero \& C. J. Herrera. 1987. Taxonomic inventory and survey activity for natural enemies of the cassava mites (Mononychellus spp.) in the Americas. Insect Sci. Appl. 8: 845-849.

Braun, A. R, J. M. Cuerrero, A. C. Bellotti \& L. T. Wilson. 1987a. Relative toxicity of permethrin to Mononychellus progresivus Doreste and Tetranychus urticue Koch (Acari: Tetranychidae) and their predators Amblyseius limonicus Garman \& McGregor (Acari: Phytoseiidae) and Oligota minuta Cameron (Coleoptera: Staphylinidae): bioassays and field validation. Environ. Entomol. 16: 545-550.

Table 3. Effect of predator exclusion on cassava dry-matter and fresh yield and on populations of tetranychid mites and the predator $A$. limonicus

\begin{tabular}{|c|c|c|c|c|c|c|}
\hline \multirow{3}{*}{ Treatment } & \multirow{2}{*}{\multicolumn{2}{|c|}{ Yield $^{a}$}} & \multicolumn{4}{|c|}{ Proportion of infested leaves } \\
\hline & & & \multirow{2}{*}{$\begin{array}{l}\text { Monony- } \\
\text { chellus } \\
\text { spp. }\end{array}$} & \multirow{2}{*}{$\begin{array}{l}\text { Tetra- } \\
\text { nychus } \\
\text { spp. }\end{array}$} & \multirow{2}{*}{$\begin{array}{l}\text { Oligo- } \\
\text { nychus } \\
\text { spp. }\end{array}$} & \multirow{2}{*}{$\begin{array}{l}\text { A. limonicus } \\
\text { mean no./ } \\
\text { leaf }\end{array}$} \\
\hline & Dry & Fresh & & & & \\
\hline Predators excluded & $3,036 \mathrm{~A}$ & $8,965 \mathrm{~A}$ & $0.15 \mathrm{~A}$ & $0.54 A$ & $0.64 \mathrm{~A}$ & $0.03 \mathrm{~A}$ \\
\hline Acaricide (no mites) & $3,982 \mathrm{AB}$ & $11,660 \mathrm{AB}$ & $0.02 \mathrm{C}$ & $0.10 \mathrm{C}$ & $0.22 B$ & $0.38 \mathrm{~A}$ \\
\hline Unsprayed (predators present) & $4,525 \mathrm{~B}$ & $11,340 \mathrm{~B}$ & $0.08 \mathrm{~B}$ & $0.31 B$ & $0.60 \mathrm{~A}$ & $1.27 \mathrm{~B}$ \\
\hline
\end{tabular}

Means and proportions followed by the same letter are not significantly different $(\mathrm{P} \leq 0.05$; Scheffe's test [Steel \& Torrie 19801$)$.

a Yields expressed as $\mathrm{kg} / \mathrm{ha}$. 
1987b. Evaluation of possible non-lethal side-effects of permethrin used in predator exclusion experiments to evaluate Amblyseius limonicus (Acari: Phytoseiidae) in biological control of cassava green mite (Acari: Tetranychidae), Environ. Entomol. 16: 1012-1018.

Chant, D. A. 1985. Internal anatomy, pp. 9-15. In W. Helle \& M. W. Sabelis [eds.], World crop pests, vol. 1B. Elsevier, Amsterdam.

Cock, J. H. 1985. Cassava: new potential for a neglected crop. Westview, Boulder, Colo.

Gilbert, N., A. P. Gutierrez, B. D. Frazer \& R. E. Jones. 1976. Ecological relationships. Freeman, San Francisco.

Iftner, D. C. \& F. R. Hall. 1983. Effects of fenvalerate and permethrin on Tetranychus urticae Koch (Acari: Tetranychidae) dispersal behavior. Environ. Entomol. 12: 1782-1786.

IITA. 1985. Biological control of cassava mealybug and green spider mite. IITA Africa-wide Biological
Control Project Information Series. No. 16. IITA, Ibadan, Nigeria.

Keating, B. A., J. P. Evenson \& S. Fukai. 1979. Environmental effects on growth and development of cassava (Manihot esculenta Crantz). II. Crop growth rate and biomass yield. Field Crops Res. 5: 283-292.

SAS Institute. 1985. SAS user's guide: statistics. SAS Institute, Cary, N.C.

Steel, R. C. D. \& J. H. Torrie. 1980. Principles and procedures of statistics. McGraw-Hill, New York.

Toro, J. C. \& A. Caiias. 1982. Determinacion del contenido de materia seca y almidon en yuca por el sistema de gravedad especifica, pp. 567-575. In C. E. Dominguez [ed.], Yuca: investigacion, produccion y utilizacion. Centro Internacional de Agricultura Tropical, Cali, Colombia.

Received for publication 20 October 1987; accepted 29 July 1988. 